\title{
Anti-CD33 Monoclonal Antibody-DM4 Conjugate AVE9633
}

National Cancer Institute

\section{Source}

National Cancer Institute. Anti-CD33 Monoclonal Antibody-DM4 Conjugate AVE9633. NCI

Thesaurus. Code C71523.

An immunoconjug ate consisting of the humanized monoclonal antibody huMy9-6

conjug ated to the cytotoxic maytansinoid DM4 with potential antineoplastic activity. The monoclonal antibody portion of anti-CD33 monoclonal antibody-DM4 conjug ate AVE9633 specifically binds to the cell surface antigen CD33 expressed on myeloid leukemia cells; upon internalization, the DM4 moiety is released, binds tubulin, and disrupts microtubule assembly/disassembly dynamics, resulting in the inhibition of cell division and cell growth in myeloid leukemia cells that express CD33. CD33 is expressed on normal non-pluripotent hematopoietic stem cells as well as on myeloid leukemia cells. 